Crop Breeding and Applied Biotechnology 15: 33-39, 2015

Brazilian Society of Plant Breeding. Printed in Brazil

NOTE

http://dx.doi.org/10.1590/1984-70332015v15n1n5

\title{
Diallel analysis of popcorn lines and hybrids for baby corn production
}

Lucas Rafael de Souza Camacho ${ }^{1 *}$, Carlos Alberto Scapim ${ }^{1}$, Henrique José Camargo Senhorinho ${ }^{1}$ and Thiago Vincenzi Conrado $^{1}$

Received 28 January 2014

Accepted 3 July 2014

\begin{abstract}
The aim of this study was to evaluate the combining ability of popcorn lines and hybrids with favorable traits for baby corn production, using lines extracted from the major genotypes of the Brazilian germplasm. From nine popcorn lines, derived from the genotypes Zélia, CMS 42, CMS 43, UEM M2, Zaeli and IAC 112, 36 single-cross hybrids were obtained without reciprocals. In partial diallel crosses, 25 single-cross hybrids were obtained, derived from crosses of five lines of the Zaeli (group I) with five lines from IAC 112 (group II). We recommend using lines derived from Zaeli and CMS 42 in hybrid breeding programs for higher ear yields. The lines P9.5.1 and P9.5.5 (group I) and P8.3 and P8.5 (group II) can be recommended for recombination within each group and for the formation of two synthetic populations for recurrent selection, in order to increase ear yield.
\end{abstract}

Key words: Zea mays L., breeding, combining ability.

\section{INTRODUCTION}

Baby corn are young and unfertilized corn ears with 2-3 $\mathrm{cm}$ emerged silks. Baby corn can be eaten raw and included in the diet in manifold ways, e.g., in salad, chutney, pakora, soup, preserves, among others (Dass et al. 2009, Hooda and Kawatra 2013). When these corn ears are consumed, they are almost free of residual effects of pesticides, because they are still covered by husk leaves and well-protected from insects and diseases when harvested in this phase (Dhasarathan et al. 2012).

Brazil has a promising market for baby corn because of the growing demand and nearly inexistent production. There is also the possibility of export to other markets, especially those that already import Brazilian plant products. Aside from supplying the growing domestic demand, this product could be included in the list of exported goods, taking advantage of the existing export chain of fruits, ornamental plants and other products (Almeida et al. 2005).

But currently, attention is focused on India, for allowing foreign exchange trading at an international level, generating higher economic returns for the farmers. Almost all marketed baby corn is imported from low-cost labor countries, as in the case of India, where corn harvest and husking are done by hand (Ranjan et al. 2013). Because of its strategic location, India will export to many Asian, European and Persian Gulf countries. Baby corn has come to play an important role in stabilizing the livelihood security and increasing the yield of farmers in peri-urban areas (Dass et al. 2009).

Due to the limited number of studies on baby corn, no high-yielding cultivars were developed for the market. Currently some early-maturing corn cultivars, originally destined for grain production, are used for baby corn production (Dhasarathan et al. 2012). In Brazil there are still no reports of breeding programs for specific maize varieties for baby corn production. Among the genotypes for grain production, some are possibly better-suited than others for baby corn production. The identification of these cultivars would allow their recommendation to farmers or their use as parents in breeding programs (DoVale et al. 2011).

Breeders obtain abundant information from diallel analysis, which is often used in breeding programs of different crops, due to its efficiency in selecting parents for crosses resulting in hybrids with desirable phenotypes. This analysis provides estimates of general and specific combining ability, as well as information about the predominance of genes with additive and non-additive effects in the trait

\footnotetext{
${ }^{1}$ Universidade Estadual de Maringá (UEM), Departamento de Agronomia, Avenida Colombo 5790, Maringá, 87.020-900, PR, Brazil. *E-mail: lrscamacho@gmail.com
} 
control (Rodrigues et al. 2009).

The aim of this study was to evaluate the combining ability of popcorn lines and hybrids with favorable traits for the production of baby corn in lines derived from the major genotypes of the Brazilian germplasm.

\section{MATERIAL AND METHODS}

Single-cross hybrids were bred in the growing season of 2006/2007 and the experiments were carried out in 2007/2008, on the Fazenda Experimental de Iguatemi (UEM), in Maringá, Paraná (PR), in an area with a dystrophic Red Latosol (Oxisol). The regional mean annual average rainfall is $1500 \mathrm{~mm}$ and mean annual temperature $19^{\circ} \mathrm{C}$.

Two diallels were used. The plant material used in the diallels is presented in Table 1. Nine $\mathrm{S}_{8}$ popcorn lines derived from six parents were crossed in a diallel scheme without reciprocals, resulting in the establishment of 36 single crosses. To obtain single-cross hybrids of the partial diallel, five $\mathrm{S}_{8}$ lines of genotype Zaeli (group I) were crossed with five $\mathrm{S}_{8}$ lines derived from the single-cross hybrid IAC-112 (group II). The lines of group I were used as female parents in the crosses. Genotypes Zaeli and IAC-112 were selected to form the groups of the partial diallel, for being adapted to temperate and tropical climate, respectively. Lines in the eighth generation of selfing were used to ensure a high level of homozygous genotypes.
Two experiments were conducted for each diallel. In both, five commercial popcorn hybrids were used as controls Jade (triple-cross hybrid) and Zelia (triple-cross hybrid) of Pioneer, IAC-112 (modified single-cross hybrid) and IAC-125 (top-cross hybrid) of the Agronomic Institute of Campinas, and BRS-Angela (open-pollinated variety) of the Brazilian Agricultural Research Corporation (Embrapa). An open-pollinated variety used by small farmers in the region of Cascavel-PR, called Thai corn, was used only in the experiment with the balanced diallel, totaling six controls.

The experiments were evaluated in a randomized complete block design with four replications for the balanced diallel and with three replications for the partial diallel. The experimental plots consisted of one 5-m long row and were spaced $0.90 \mathrm{~m}$ apart, with an initial population of 190,000 seeds ha ${ }^{-1}$, thinned to 180,000 plants ha ${ }^{-1}$.

Fertilization at sowing consisted of $350 \mathrm{~kg} \mathrm{ha}^{-1}$ of 8-2818 NPK fertilizer. Fertilization was fractionated in two 150 $\mathrm{kg} \mathrm{ha}^{-1}$ applications, the first in V2 and the second in the V6 stage, using urea as $\mathrm{N}$ source. Sowing was done by hand.

A 20-L backpack sprayer was used for desiccation with $4 \mathrm{~L} \mathrm{ha}^{-1}$ glyphosate $+30 \mathrm{~mL} \mathrm{ha}^{-1}$ lambda cialotrina in weed control and initial bedbug control, followed by the application of $3 \mathrm{~L} \mathrm{ha}^{-1}$ atrazine as pre-emergent herbicide and three applications of $250 \mathrm{~mL} \mathrm{ha}^{-1}$ profenofos $+100 \mathrm{~mL}$ $\mathrm{ha}^{-1}$ Lufenuron to control weed pests.

Table 1. Relation of parental lines from which popcorn lines were derived for the balanced diallel of popcorn, using method 4 of Griffing and in the diallel proposed by Griffing, adapted for partial diallels

\begin{tabular}{|c|c|c|}
\hline Parents & Plant material/Institution & Derived line and code \\
\hline \multicolumn{3}{|c|}{ Balanced diallel } \\
\hline Zélia & Triple-cross hybrid/ Pioneer & L1.1 \\
\hline CMS-42 & Composite variety of Embrapa-CNPMS & L3.2 \\
\hline UEM-M2 & Open-pollinated variety/ UEM & $\begin{array}{l}\text { L7.1 } \\
\text { L7.4 }\end{array}$ \\
\hline \multicolumn{3}{|c|}{ Partial diallel } \\
\hline Zélia & Triple-cross hybrid/ Pioneer & P9.5.1 \\
\hline Zélia & Triple-cross hybrid/ Pioneer & P9.5.2 \\
\hline Zélia & Triple-cross hybrid/ Pioneer & P9.5.3 \\
\hline IAC-112 & Modified single-cross hybrid / IAC-SP & P8.2 \\
\hline IAC-112 & Modified single-cross hybrid / IAC-SP & P8.3 \\
\hline IAC-112 & Modified single-cross hybrid / IAC-SP & P8.4 \\
\hline IAC-112 & Modified single-cross hybrid / IAC-SP & P8.5 \\
\hline
\end{tabular}


The crop was harvested daily once the silks of the ears were $2-3 \mathrm{~cm}$ long, preferably in moments of the day with mild temperatures.

After husking, the ear diameter (ED) and ear length (EL) were measured (in $\mathrm{mm}$ ) with a digital caliper, determined by the simple arithmetic average of 15 ears per plot and ear yield (EY) was assessed with an analytical balance, extrapolating the weight of ears per plot to $\mathrm{kg} \mathrm{ha}^{-1}$.

The data were subjected to analysis of variance and the means compared by the Scott-Knott test at 10\% probability, using the SAS (SAS Institute 1996) statistical program. The mean squares of the treatments of the analysis of variance of the experiments were decomposed in hybrid, controls and between groups (hybrids and controls), and the mean squares of the error and degrees of freedom related only to the hybrids were used in the diallelic analyses. The unprecedented SAS routine for the Scott-Knott test is available at link: http://www.idroids.com.br/rotinaSASSK.txt.

For the genetic analyses we used method 4 for balanced diallels of Griffing (1956). For partial diallels, we used the model proposed by Griffing (1956), adapted for partial diallels (Cruz et al. 2004). Both analyses were performed using software Genes (Cruz 2006).

\section{RESULTS AND DISCUSSION}

The results of the analyses of variance for the balanced diallel indicated significant differences between treatments for all traits, which shows the genetic variability demonstrated in the phenotypic differences between genotypes. The coefficients of variation (Table 2) for EL and ED were similar to those reported by Rodrigues and Silva (2002). The coefficient of variation for EY was similar to that observed by DoVale et al. (2011), when evaluating 10 commercial maize cultivars suited for baby corn production. Other authors such as Resende and Duarte (2007), using the selection accuracy as parameter for assessing the quality of experiments of cultivar evaluation. According to the authors, the values of the estimates of selection accuracy for EL and ED could be classified as high experimental precision, while the value for EY would be estimated as moderate. Santos et al. (2014) studying the agronomic performance of 16 super-sweet corn genotypes, assessed the quality of EL and ED evaluations and the estimated values of selection accuracy similar to this study.

The average results found for EY in the balanced diallel were similar to those reported by Almeida et al. (2005), who tested common commercial maize genotypes. However, these results were inferior to those of Rodrigues et al. (2004), who evaluated genotypes destined specifically for baby corn production. It is noteworthy that the balanced diallel was evaluated in the second growing season, during which environmental stresses are common that cause reductions in EY. Thus, despite the low means, crosses with EY could be identified. Fifteen hybrids had an equally excellent performance for this trait, not differing significantly from each other in relation to the controls Jade, IAC 112 and IAC-125 by the Scott-Knott test (Scott and Knott 1974) at $10 \%$ probability (Table 3 ). Scott-Knott test at $10 \%$ probability were used in order to detect significant differences more efficiently.

In the balanced diallel, the mean squares for specific combining ability (SCA) were significant at $5 \%$ probability for EL and ED (Table 2), while for EY, significant at $5 \%$ probability only for general combining ability (GCA). This indicates the existence of genetic variability, resulting from the action of additive effects for EL and ED, and non-additive control of gene expression for EY. It is also important to mention the genetic variability in parental lines with a high potential for yield-related traits of baby corn as well as the possibility of specific combinations of lines in hybrid breeding.

Table 2. Estimates of mean squares of the general combining ability (GCA) and specific combining ability (SCA) for ear length (EL), ear diameter (ED) and ear yield (EY) for baby corn production, according to method 4 of Griffing and for ear yield (EYp) according to the model of Griffing adapted for partial diallels

\begin{tabular}{|c|c|c|c|c|c|c|c|}
\hline \multirow{2}{*}{ Sources of variation } & \multirow{2}{*}{ df } & \multicolumn{3}{|c|}{ Mean squares } & \multirow{2}{*}{ Sources of variation } & \multirow{2}{*}{ df } & \multirow{2}{*}{$\begin{array}{c}\text { Mean squares } \\
\text { EYp }\end{array}$} \\
\hline & & EL & ED & EY & & & \\
\hline GCA & 8 & 1.503 & 0.017 & $67674.54^{*}$ & GCA G-I & 4 & $35126^{*}$ \\
\hline SCA & 27 & $4.025^{*}$ & $0.035^{*}$ & 24444.79 & GCA G-II & 4 & $131370^{*}$ \\
\hline \multirow[t]{2}{*}{ Error } & 123 & 0.99 & 0.011 & 19123.87 & SCA IxII & 16 & $115157^{*}$ \\
\hline & & & & & Error & 58 & 5057.23 \\
\hline $\mathrm{CV}(\%)$ & & 9.80 & 8.29 & 37.62 & $\mathrm{CV}(\%)$ & & 11.31 \\
\hline
\end{tabular}

"significant at $5 \%$ probability. 
LRS Camacho et al.

With regard to trait EL, Rodrigues et al. (2004) reported significance at $1 \%$ probability for both GCA and for SCA, in seven prolific $\mathrm{S}_{2}$ baby corn families. For ED, the same authors noted the significance for GCA only, at $1 \%$ prob- ability. For both traits, these results disagree with ours. It is worth remembering that these results are specific to the group of lines studied, so differences in results between scientific papers are to be expected.

Table 3. Means of ear length (EL), ear diameter (ED) and ear yield (EY) in the experiment based on the balanced diallel of popcorn, according to method 4 of Griffing

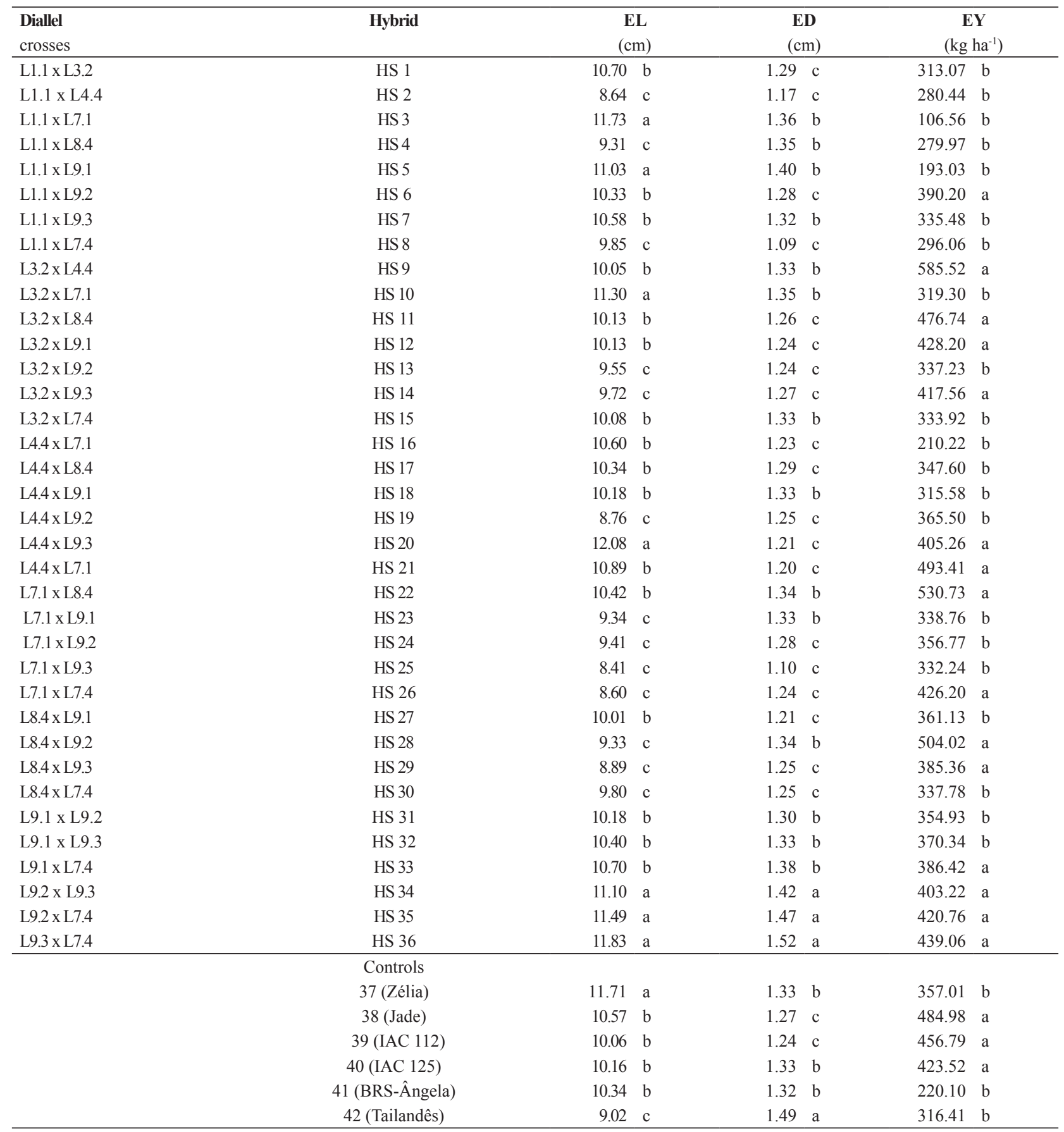

Means followed by the same letter belong to the same group, according to the grouping criteria of Scott-Knott, at 10\% probability. 
The lines L8.4 and L3.2 had very high positive $\hat{G}_{i}$ values (42,108 and 40,424 respectively), with a noteworthy ER, particularly in view of their presence in the composition of most higher-yielding hybrids. These estimates indicate both lines as promising for breeding programs of hybrids with higher EY. The differences between the effects of the two parents were considered significant when these exceeded the standard deviation at least twice (Singh and Chaudhary 1979).

The estimates of the SCA effects $\left(\hat{S}_{i j}\right)$ and standard deviations for the 36 single-cross popcorn hybrids for evaluation of baby corn are presented in Table 4 . Low $\hat{S}_{i j}$ values indicate that the hybrid performance can be predicted based on the GCA of their parents (Cruz et al. 2004).

According to the results obtained for EL, by means of SCA estimates, the hybrids with high positive $\hat{S}_{i j}$ values were HS 3, HS 20, HS 35, and HS 36. For ED, the best hybrids were HS 35 and HS 36.

The analysis of variance of the experiment based on the partial diallel indicated the existence of significant differences between treatment means only for EY at 5\% probability. The estimate of the coefficient of variation (Table 2) for this trait is consistent with that observed by Rodrigues and Silva (2002). The estimated value of selection accuracy for this trait fits into the class of experimental precision very high (Resende and Duarte 2007).

Five hybrids stood out in the partial diallel with exceptional EY: P9.5.3 x P8.3 (969.27), P9.5.5 x P8.5 (951.85), P9.5.1 x P8.5 (941.15), P9.5.5 x P8.2 (929.63), P9.5.4 x P8.4 (882.59), and IAC-112 (998.51), with no significant difference from each other by the Scott-Knott test at $10 \%$ probability.

In the analysis using the Griffing (1956) model, adapted for partial diallels (Cruz et al. 2004), significant differences were detected for GCA $(p<0.05)$ in relation to EY, for the lines of group I and II, indicating variation between the lines within each group (Table 2). The SCA effects were also significant $(p<0.05)$, indicating the existence of variability in the non-additive genetic effects. The magnitude of the mean squares (Table 2) indicated that the GCA values for group II and for SCA are close, i.e., the additive gene effects of the lines of group II and the non-additive gene effects were equally relevant. On the other hand, the mean square of the GCA of the group I lines was well below the values of GCA for group II and SCA, indicating that additive genetic effects of the group I lines are less important than the additive gene effects of group II lines and the non-additive genetic effects.
The estimates of GCA, SCA and of the standard deviations for EY for the partial diallel are shown in Table 5. In group I, the lines P9.5.1 and P9.5.5 were selected for their high positive $\hat{G}_{i}$ values, while in group II, P8.3 and P8.5 stood out with high positive $\hat{G}_{i}$ values. These lines are recommendable for crosses within each group, to develop synthetic varieties and for breeding programs for higheryielding hybrids.

Table 4. Estimates of the effects of specific combining ability $\left(\hat{S}_{\text {. }}\right)$ and standard deviations (SD) on ear length (EL) and ear diameter (ED) for the balanced diallel in popcorn, according to method 4 of Griffing

\begin{tabular}{|c|c|c|c|}
\hline$\hat{S}_{i j}$ & HS & EL & ED \\
\hline L1.1 x L3.2 & HS 1 & 0.363 & 0.014 \\
\hline L $1.1 \times$ L 4.4 & HS 2 & -1.680 & -0.063 \\
\hline L1.1 x L7.1 & HS 3 & 1.658 & 0.095 \\
\hline L1.1 x L8.4 & HS 4 & -0.537 & 0.077 \\
\hline L1.1 x L9.1 & HS 5 & 0.649 & 0.094 \\
\hline L1.1 x L9.2 & HS 6 & 0.209 & -0.035 \\
\hline L1.1 x L9.3 & HS 7 & 0.050 & 0.028 \\
\hline $\mathrm{L} 1.1 \times \mathrm{L} 7.4$ & HS 8 & -0.713 & -0.210 \\
\hline $\mathrm{L} 3.2 \times \mathrm{L} 4.4$ & HS 9 & -0.197 & 0.090 \\
\hline $\mathrm{L} 3.2 \times \mathrm{L} 7.1$ & HS 10 & 1.300 & 0.078 \\
\hline $\mathrm{L} 3.2 \times \mathrm{L} 8.4$ & HS 11 & 0.356 & -0.020 \\
\hline L3.2 x L9.1 & HS 12 & -0.178 & -0.073 \\
\hline L3. $2 \times$ L9. 2 & HS 13 & -0.498 & -0.082 \\
\hline L3.2 $\times$ L9.3 & HS 14 & -0.737 & -0.029 \\
\hline $\mathrm{L} 3.2 \times \mathrm{L} 7.4$ & HS 15 & -0.410 & 0.023 \\
\hline L4.4 x L7.1 & HS 16 & 0.618 & 0.001 \\
\hline L4.4 x L8.4 & HS 17 & 0.583 & 0.053 \\
\hline L4.4 x L9.1 & HS 18 & -0.111 & 0.060 \\
\hline L4.4 x L9. 2 & HS 19 & -1.271 & -0.029 \\
\hline L4.4 x L9.3 & HS 20 & 1.640 & -0.046 \\
\hline L4.4 x L7. 1 & HS 21 & 0.418 & -0.065 \\
\hline L7.1 $\times$ L8.4 & HS 22 & 0.910 & 0.071 \\
\hline L7.1 x L9.1 & HS 23 & -0.704 & 0.028 \\
\hline L7.1 x L9. 2 & HS 24 & -0.374 & -0.030 \\
\hline L7.1 x L9.3 & HS 25 & -1.783 & -0.188 \\
\hline L7. $1 \times$ L7.4 & HS 26 & -1.625 & -0.056 \\
\hline L8.4 x L9.1 & HS 27 & 0.192 & -0.100 \\
\hline L8.4 x L9.2 & HS 28 & -0.228 & 0.021 \\
\hline L8.4 x L9.3 & HS 29 & -1.077 & -0.046 \\
\hline L8.4 x L7.4 & HS 30 & -0.200 & -0.055 \\
\hline L9.1 x L9.2 & HS 31 & 0.088 & -0.052 \\
\hline L9.1 $\times$ L9.3 & HS 32 & -0.101 & 0.001 \\
\hline L9.1 1 L 7.4 & HS 33 & 0.166 & 0.043 \\
\hline L9. $2 \times$ L9.3 & HS 34 & 0.859 & 0.083 \\
\hline L9. $2 \times$ L7.4 & HS 35 & 1.216 & 0.124 \\
\hline L9.3 $\times$ L7.4 & HS 36 & 1.148 & 0.197 \\
\hline $\mathrm{SD}\left(\hat{S}_{i j}\right)$ & & 0.22 & 0.02 \\
\hline $\operatorname{SD}\left(\hat{S}_{i j}-\hat{S}_{i k}\right)$ & & 0.33 & 0.04 \\
\hline $\mathrm{SD}\left(\hat{S}_{i j}-\hat{S}_{k l}\right)$ & & 0.30 & 0.03 \\
\hline
\end{tabular}


LRS Camacho et al.

Table 5. Estimates of the effects of general combining ability $\left(\hat{G}_{i}\right)$, specific combining ability $\left(\hat{S}_{i j}\right)$ and standard deviations (SD) on popcorn ear yield (EY) according to the model of Griffing, adapted for partial diallels

\begin{tabular}{|c|c|c|c|c|c|c|}
\hline$\hat{G}_{i}{ }^{1} \hat{G}_{i}^{{ }^{2}}$ & P8.1 & P8.2 & P8.3 & P8.4 & P8.5 & $\hat{G}_{i}$ \\
\hline P9.5.1 & 62.219 & -88.949 & -178.567 & -2.809 & 208.105 & 14.3948 \\
\hline P9.5.2 & 247.355 & -98.133 & -100.091 & 33.897 & -83.029 & -77.7712 \\
\hline P9.5.4 & -229.483 & -20.521 & 65.621 & 239.649 & -55.267 & 7.9568 \\
\hline P9.5.5 & -231.357 & 222.965 & -37.753 & -131.845 & 177.989 & 55.2108 \\
\hline $\operatorname{SD}\left(\hat{S}_{i j}^{i j^{\prime}}-\hat{S}_{i k}\right)$ & & 51.935 & $\operatorname{SD}\left(\hat{G}_{i}-\hat{G}_{i}^{\prime}\right)$ & 25.97 & & \\
\hline $\mathrm{SD}\left(\hat{S}_{i j}^{l}-\hat{S}_{k l}\right)$ & & 44.977 & & & & \\
\hline
\end{tabular}

${ }^{1}$ Group I (Zaeli)

${ }^{2}$ Group II (IAC-112)

The highest $\hat{S}_{i j}$ value was obtained by hybrid P9.5.3 x P8.3, associated with a high GCA estimate of parent P8.3, evidencing the predominance of non-additive genetic ef- fects. This hybrid can be recommended for the formation of higher-yielding synthetics and breeding of lines.

\section{Análise dialélica de linhagens e híbridos de milho-pipoca para produção de minimilho}

Resumo - O objetivo deste trabalho foi avaliar as capacidades combinatórias de linhagens e híbridos de milho-pipoca, com características favoráveis à produção de minimilho, utilizando linhagens extraídas dos principais genótipos pertencentes ao germoplasma brasileiro. A partir de nove linhagens de pipoca, extraídas dos genótipos Zélia, CMS 42, CMS 43, UEM M2, Zaeli e IAC 112, foram obtidos 36 híbridos simples, sem recíprocos. No esquema de cruzamentos dialélicos parciais, foram obtidos 25 híbridos simples, originados dos cruzamentos de cinco linhagens derivadas de Zaeli (grupo I) com cinco linhagens extraídas do IAC 112 (grupo II). Recomenda-se utilizar linhagens extraídas de Zaeli e CMS 42 em programas de obtenção de híbridos com rendimentos de espigas superiores. As linhagens P9.5.1 e P9.5.5 (grupo I) e P8.3 e P8.5 (grupo II) podem ser recomendadas para recombinação dentro de cada grupo e formação de duas populações sintéticas para seleção recorrente, visando o aumento no rendimento de espiga.

Palavras-chave: Zea mays L., melhoramento, capacidade combinatória.

\section{REFERENCES}

Almeida IPC, Silva PSL, Negreiros MZ and Barbosa Z (2005) Baby corn, green ear, and grain yield of corn cultivars. Horticultura Brasileira 23: $960-964$.

Cruz CD (2006) Programa Genes: Biometria. Editora UFV, Viçosa, 382p.

Cruz CD, Regazzi AJ and Carneiro PCS (2004) Modelos biométricos aplicados ao melhoramento genético. Editora UFV, Viçosa, 480p.

Dass S, Kaul L, Manivannan, Singode A and Chikkappa GK (2009) Single cross hybrid maize - A viable solution in the changing climate scenario. Indian Journal of Genetics and Plant Breeding 69: 331-334.

Dhasarathan M, Babu C, Iyanar K and Velayudham K (2012) Studies on genetic potential of baby corn (Zea mays L.) hybrids for yield and quality traits. Electronic Journal of Plant Breeding 3: 853-860.

DoVale JC, Fritsche-Neto R and Lima e Silva PS (2011) Índice de seleção para cultivares de milho com dupla aptidão: minimilho e milho verde. Bragantia 70: 781-787.

Griffing B (1956) Concept of general and specific combining ability in relation to diallel crossing systems. Australian Journal Biology Science 9: 463-493.
Hooda S and Kawatra A (2013) Nutritional evaluation of baby corn (zea mays). Nutrition \& Food Science 43: 68-73.

Ranjan JK, Ahmed N, Das B, Ranjan P and Mishra BK (2013) Green technology for production of baby corn (Zea mays L) under northwest Himalayan conditions. International Journal of ChemTech Research 5: 880-885.

Resende MDV and Duarte JB (2007) Precisão e controle de qualidade em experimentos de avaliação de cultivares. Pesquisa Agropecuária Tropical 37: 182-194.

Rodrigues F, Pinho RGV, Albuquerque CJB, Filho EMF and Goulart JC (2009) Capacidade de combinação entre linhagens de milho visando à produção de milho verde. Bragantia 68: 75-84.

Rodrigues LR, Silva N and Mori ES (2004) Avaliação de sete famílias $\mathrm{S} 2$ prolíficas de minimilho para a produção de híbridos. Bragantia 63: $31-38$.

Rodrigues RFR and Silva N (2002) Combining ability in baby corn inbred lines (Zea mays L.). Crop Breeding and Applied Biotecnology 2: 361-368.

Santos PHAD, Pereira MG, Trindade RS, Cunha KS, Entringer GC and 
Diallel analysis of popcorn lines and hybrids for baby corn production

Vettorazzi JCF (2014) Agronomic performance of super-sweet corn genotypes in the north of Rio de Janeiro. Crop Breeding and Applied Biotechnology 14: 8-14.

SAS Institute (1996) SAS/STAT: user's guide. SAS Institute, Cary, 1028p.
Scott AJ and Knott MA (1974) A cluster analysis method for grouping means in the analysis of variance. Biometrics 30: 507-512.

Singh RK and Chaudhary BD (1979) Biometrical methods in quantitative genetic analysis. Kalyani, New Delhi, 304p. 